\title{
POTENTIAL USE OF COMMERCIAL KA-BAND TO AUGMENT WIDEBAND MILSATCOM SYSTEMS
}

\author{
Gary J. Graupmann, CAPTAIN USN, Kenneth Ota, John Isaacson, and Paul Thomas \\ Space and Naval Warfare Systems Command, PMW 176 \\ 4301 Pacific Highway \\ San Diego, CA 92110-3127 \\ Kurt A. Fiscko \\ Integrated Systems Control \\ 2243 San Diego Avenue, Suite 200 \\ San Diego, CA 92110-2924
}

\begin{abstract}
A DoD study team is presently examining future commercial Ka-band SatCom systems for their potential to meet DoD communication requirements. Substantial commercial capacity is expected to exist in 2010, offering significant potential to augment DoD-owned systems. Although a DoD Candidate Commercial Requirements Document has recently been published, more requirements definition and refinement is needed. Possible DoD courses of action range from anchor tenancy to "wait and see." The DoD study team has recommended a course of action regarding commercial broadband systems to the senior DoD leadership.
\end{abstract}

\section{INTRODUCTION}

The introduction of several new commercial Kaband satellite communications systems [1] over the next five years promises dramatic increases in capacity. By 2010 the Emerging Requirements Data Base (ERDB) [2] predicts that U.S. military requirements for satellite communications will exceed $11 \mathrm{Gbps}$, eclipsing projected DoD-owned satellite communications capabilities. Even the launch of the DSCS Wideband Gapfiller System (WGS) in 2004 will at best only temporarily bring MILSATCOM supply and demand into equilibrium. The use of commercial systems to augment DoD-owned systems must be considered.

In August 1998 the Senior SatCom Steering Group (SSG) tasked Navy and the Defense Information Systems Agency (DISA) to 'Lead, with joint participation, evaluation of commercial business cases for emerging wideband commercial satellite communications systems." Subsequently, Navy and DISA initiated a study effort to 1) determine technical capabilities of $\mathrm{Ka}$-systems, 2) explore business cases for commercial Ka-leverage, 3) influence commercial designs through an increased understanding of DoD requirements, and 4) develop strategy for integration of commercial $\mathrm{Ka}$ and government systems (i.e., Defense Information Systems Network, DISN).

\section{MILSATCOM REQUIREMENTS}

Requirements for Military Satellite Communications are clearly outlined in the USSPACECOM DoD Advanced MILSATCOM Capstone Requirements Document [3]. These required system characteristics are depicted in Figure 1. 
In July 1998 DISA was tasked by the SSG to determine those requirements contained in the ERDB that could potentially be satisfied using commercial systems. A Candidate Commercial Requirements Document was released in January 1999 in response to the SSG tasking. This is considered to be a "living" document, and refinements and enhancements to the DISA document are expected. Table 1 outlines the Capstone Key Performance Parameters for MILSATCOM Systems as identified in the Candidate Commercial Requirements Document.

\begin{tabular}{|c|c|c|}
\hline Parameter & Threshold & Objective \\
\hline Coverage & $\begin{array}{l}\text { Ability to provide MILSATCOM service when/where needed in } \\
\text { areas north of } 65 \text { degrees south latitude. }\end{array}$ & $\begin{array}{l}\text { Ability to provide MILSAT- } \\
\text { COM at all latitudes and } \\
\text { longitudes. }\end{array}$ \\
\hline Capacity & $\begin{array}{l}\text { Provide requisite amounts of wideband and narrowband } \\
\text { capabilities (throughputs and accesses) to warfighters and their } \\
\text { supporting infrastructures: } \\
\text { - Wideband (symmetric, asymmetric and broadcast) } \\
\text { - Focus on deployed forces and outside the continental } \\
\text { United States (OCONUS) warrior support activities (e.g, } \\
\text { Defense Information System Network [DISN], the } \\
\text { intelligence community, etc.) } \\
\text { - Protected communications } \\
\text { - Narrowband (netted and other topologies) } \\
\text { - Sustain UHF Follow-on Satellite Communications System } \\
\text { (UFO) capabilities and augment with mobile satellite } \\
\text { service (MSS)/personal communications service (PCS) }\end{array}$ & $\begin{array}{l}\text { Threshold plus support } \\
\text { projected growth rates. } \\
\text { Support data rates up to } 64 \\
\text { kbps into hand held } \\
\text { narrowband devices. }\end{array}$ \\
\hline Protection & $\begin{array}{l}\text { Provide levels of protection to subsets of the overall } \\
\text { MILSATCOM capacities: } \\
\text { - Survivable and anti-jam communications for National } \\
\text { Command Authority (NCA)/Single Integrated Operations } \\
\text { Plan (SIOP) forces } \\
\text { Anti-jam (AJ) for "front line" command and control (C2) } \\
\text { and common user networks } \\
\text { Low probability of intercept (LPI)/low probability of } \\
\text { detection (LPD) for critical tactical and strategic } \\
\text { covert/sensitive users } \\
\text { U.S. control for selected users (e.g., vital diplomatic and } \\
\text { intelligence needs and selected tactical networks) } \\
\text { Prevent unauthorized access to, or disclosure of, information. }\end{array}$ & $\begin{array}{l}\text { Threshold plus provide AJ, } \\
\text { LPI/LPD and/or U.S. control } \\
\text { for lower priority tactical, } \\
\text { strategic and supporting } \\
\text { networks. Automatically } \\
\text { detect, characterize, and } \\
\text { neutralize offensive } \\
\text { information operations. }\end{array}$ \\
\hline $\begin{array}{l}\text { Access and } \\
\text { Control }\end{array}$ & $\begin{array}{l}\text { CINCs/joint task forces dictate resource utilization over } \\
\text { apportioned resources and plan, allocate, and schedule access } \\
\text { within fractions of hours to a few hours. } \\
\text { Rapidly and dynamically configure and reconfigure } \\
\text { MILSATCOM resources within a few hours to fractions of } \\
\text { hours (selected networks within minutes). }\end{array}$ & $\begin{array}{l}\text { Near-real-time authorization, } \\
\text { denial, preemption of } \\
\text { accesses. } \\
\text { Accomplish dynamic } \\
\text { resource configuration within } \\
\text { a few minutes. }\end{array}$ \\
\hline Interoperability & $\begin{array}{l}\text { Interoperability between/among CINC and joint task force (JTF) } \\
\text { components (e.g, land, air, naval, mobility, combat support, and } \\
\text { special operations forces [SOF]). } \\
\text { Fully integrated MILSATCOM as the space portion of the } \\
\text { Defense Information Infrastructure (DII). }\end{array}$ & $\begin{array}{l}\text { Threshold plus interoper- } \\
\text { ability with allies and } \\
\text { coalition partners and other } \\
\text { federal agencies (non-DoD). }\end{array}$ \\
\hline Flexibility & $\begin{array}{l}\text { Terminal types including handheld, fixed, transportable, } \\
\text { submarine, ship, aircraft, and fixed control/gateway facilities }\end{array}$ & \\
\hline $\begin{array}{l}\text { Quality of } \\
\text { Service }\end{array}$ & Commercial Standards & Voice Recognition \\
\hline
\end{tabular}

Table 1. Key Performance Parameters 


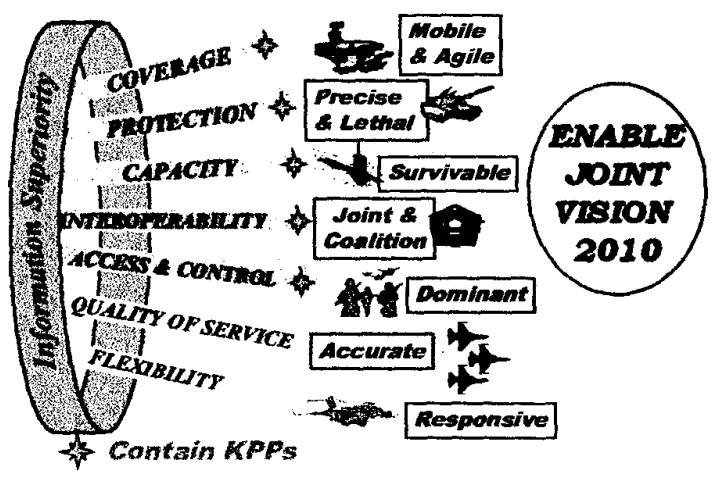

Figure 1. Required System Characteristics

\section{INVESTIGATION METHODOLOGY}

Preliminary information was obtained from a number of sources, including a Mitre Corporation study [4] and several commercially available studies [5], [6], [7]. In September 1998 the DoD team released a Request for Information in the Commerce Business Daily. A detailed plan of action and milestones was later developed, and was subsequently briefed to a joint action officer forum in December 1998. In January 1999 a Commercial Ka-band SatCom Industry Day was held in conjunction with the AFCEA West Conference in San Diego, California. Following the Industry Day, two rounds of one-on-one meetings with industry occurred in Crystal City, Virginia, during which interested companies made two-hour presentations to the DoD team. As a result of these initial meetings with industry, a comprehensive list of questions for industry was prepared and released in March 1999. These questions explored a broad range of areas concerning business cases, technical capabilities, risk, and integration and standardization issues. Next, a series of visits by the DoD team to vendor facilities allowed each commercial provider an opportunity to provide the team still another level of detail regarding the vendor's plans and capabilities.
By June of 1999 the DoD team had received inputs from 23 companies. Those providing products/services other than space segment are depicted in Table 2.

- Allied Signal
- Arrowhead
- Austin Info Systems
- Communication Solutions
- Harris
- Interferometrics
- Linkabit
- Raytheon (Systems Company)
- Stanford Telecom
- Telestar
- Vertex Antenna Systems

Table 2. Component Companies

Potential space segment providers are listed in Table 3. Although most companies provided a significant amount of proprietary data to the DoD team, no proprietary data is included in this paper. Hence, data in Table 3 is also found in other open sources.

\section{ISSUES}

Many issues regarding the possible procurement of commercial Ka-band SatCom services and products remain to be resolved. Principal among these are the need for polar and/or open ocean coverage, latency, onboard processing, and spectrum authorization. If polar and/or open ocean coverage are firm requirements for DoD use of commercial Kaband SatCom then, based on Table 3, the potential field of vendors gets narrowed considerably. If low propagation latency is necessary then, once again, the nongeosynchronous systems become the only potential candidates. If DoD intends to use 


$\begin{array}{ll}\text { System Name } & \text { OperatoriProposer } \\ \text { @Contact } & \text { @Contact } \\ \text { Astrolink } & \text { Lockheed Martin } \\ \text { Boeing Ku-band NGSO FSS } & \text { Boeing } \\ \text { Cyberstar } & \text { Loral Skynet } \\ \text { GE*Star } & \text { GE Americom } \\ \text { Ka-Star } & \text { KaSTAR } \\ \text { PAS-10, 11, 14-20 } & \text { PanAmSat } \\ \text { Skybridge } & \text { Skybridge } \\ \text { Spaceway } & \text { Hughes } \\ \text { Spaceway EXP } & \text { Hughes } \\ \text { Spaceway NGSO } & \text { Hughes } \\ \text { Teledesic } & \text { Teledesic } \\ \text { VisionStar } & \text { VisionStar }\end{array}$

\begin{tabular}{cc} 
Coverage & Orblt Typ \\
\cline { 2 - 2 } Global & MEO \\
Land Mass & GEO \\
Global & MEO \\
Land Mass & GEO \\
Land Mass & GEO \\
U.S. & GEO \\
Land Mass & GEO \\
Global, less poles & LEO \\
Land Mass & GEO \\
Land Mass & GEO \\
Global & MEO \\
Global & LEO \\
U.S. & GEO
\end{tabular}

Table 3. Space Segment Providers

commercial Ka-band services in mobile platforms on a co-primary basis, then no system listed in Table 3 is acceptable because none is currently licensed (nor have any applied for a license) to operate in the Mobile Satellite Service (MSS).

As of this writing, it is unknown whether the DoD-owned Gapfiller system will employ onboard baseband processing for its Kaband capabilities. Many of the systems in Table 3 will employ onboard processing. Terminal level compatibility between commercial Ka-band systems and the Gapfiller satellites is bighly desirable and could lead to significant cost savings and flexibility for the DoD. While many of the systems listed in Table 3 have plans to produce extremely low-cost user terminals, selection factors regarding DoD terminals are much more complex and include such concerns as limited space, special shock and vibration requirements, special environmental requirements, and legacy equipment.

Additional issues that must be resolved include data-level encryption operating over processed satellite systems, availability (rain fade characteristics), U.S. control of gateways (to protect geo-location information), and the availability and cost of phased array antennas.

Factoring into nearly all decisions regarding the procurement of commercial Ka-band services and products is the total cost of ownership to the DoD. In today's budgetconstrained environment, cost is an independent variable when determining requirements. Resolving these requirements issues can only be accomplished while considering the possible cost impacts of each decision opportunity mentioned here.

\section{THE WAY AHEAD}

Many metrics have been suggested to gauge the potential of the systems listed in Table 3 to achieve commercial success. Among these metrics are license status, strategic equity status, and system cost per Gbps of throughput capacity. This last metric is often considered an indicator of the relative rate structures for the commercial systems.

While the combined throughput of all systems listed in Table 3 substantially exceeds 1 Tbps, only a fraction of the 
systems listed are expected to reach initial operational capability. Although DoD's capacity demands are expected to grow dramatically, DoD's commercial bandwidth augmentation requirements represent less than $1 \%$ of expected commercial $\mathrm{Ka}$-band SatCom capacity in the year 2010. The conclusion here is that, based on potential sales, DoD has little probability of influencing commercial systems' design to accommodate special DoD requirements. An alternative method of influencing commercial designs could be to purchase/reserve a fraction of system capacity prior to IOC (i.e., so-called anchor tenancy).

Anchor tenancy typically requires significant up-front investment of capital, becoming, in effect, a strategic partner in a particular system. Anchor tenancy in these commercial Ka-band systems is difficult in DoD, however, for a number of reasons. There is currently no funding line in the DoD budget to support such an endeavor, and these funds would be needed now in order to influence commercial system design. Secondly, no Ka-band system is assured of commercial success, so the entire DoD investment could be lost if the selected system is a commercial failure. Third, no commercial Ka-band system has filed for MSS, meaning that the DoD could be forced to turn off its mobile commercial $\mathrm{Ka}$ transmitters under certain circumstances. Finally, capabilities of nearly every system listed in Table 3 are changing with time.

An alternative to anchor tenancy would be to continue to observe the development of commercial Ka systems, and purchase/lease services when/if they become available. Continuing to work with Ka-band vendors to insure that they understand DoD requirements, allowing them to meet whatever DoD requirements they deem appropriate, could enhance this approach. Although there is no significant up-front investment (and potential loss thereof) required in this alternative approach, the risk of this approach is that key DoD requirements may never be met by any commercial Ka-band system. There is also the risk that the capacities of commercial systems may be entirely sold out prior to launch. Recent experience with the Iridium system, however, suggests that will probably not be the case.

In August 1999 the DoD commercial Kaband SatCom study team briefed the SSG and recommended a strategy for DoD. This strategy minimizes the risk and cost to the DoD, while insuring its ability to perform its global mission. Global communications is a key enabler of the Joint Vision 2010 Strategy. To enhance communications with potential Ka-band vendors, the DoD study team has established a web page regarding its effort.

\section{SUMMARY}

Commercial Ka-band SatCom systems are being investigated for their potential to augment DoD-owned systems. A significant number of systems are planned for activation within the next five years, with varying capabilities. DoD must continue to refine and define its commercial SatCom requirements, and work with industry to insure that its requirements are understood. Although probably too early now to pick any commercial Ka-band "winners," the DoD team will soon be recommending a course of action to the SSG that will minimize the DoD's risks and will maximize its communications capabilities. 


\section{REFERENCES}

[1] Roger J. Rusch and Charles Emmert, Technical and Business Review of the Latest Broadband Satellite Systems, Fourth Ka Band Utilization Conference, November 98.

[2] Emerging Requirements Data Base (ERDB) Ver 5.1, Rev 1, Sep 98.

[3] Advanced Military Satellite Communications Capstone Requirements Document, USSPACECOM, DoD, April 98.

[4] Commercial Satellite Communications Systems and the DoD, Mitre Corps, Oct 98.

[5] Financial and Business Evaluation of New MultiMedia Satellite Systems, TelAstra, Inc, Sep 98.

[6] The Ka-Band Report, DTT Consulting, 1997.

[7] World Broadband Satellite Service and Equipment Markets Ka-Band Repört, Frost \& Sullivan, 1998. 